\title{
Property, predators and patrons in Romania
}

Thomas Sikor and Stefan Dorondel

\author{
To appear as Chapter 5 in \\ Thomas Sikor, Stefan Dorondel, Johannes Stahl and To Xuan Phuc \\ Propertizing Projects: \\ Postsocialist Transformations in Rural Albania, Romania and Vietnam \\ Book manuscript under preparation
}

When Stefan walked into the beech, oak and fir forests surrounding Dragomireşti in 2004, he could not help it but be impressed. One row of solid trees lined up against another. The trees - ordered in neat stands of homogeneous age classes - indicated the sound silvicultural practice applied by the Ocolul Silvic Mihăeşti during socialism. Yet Stefan also discovered clearings that dissected the forests. Ranging from a single ha to several dozens, the clearings attested to recent logging. Moreover, the loggers had perplexingly left tree trunks of approximately one meter height in many clearings (see Figure 1). Why had the loggers left valuable wood behind? When Stefan asked villagers about this he got a unanimous reply: it was Rudari who did the logging. They left stumps because "Rudari are too lazy to bend down for cutting a tree near the ground". Moreover, villagers explained, Rudari were not only lazy but also thieves, as it was villagers' forest that they had logged over without permission.

When Stefan went on to Dragova, he did not find any stumps of similar height in the oak and fir forests there. There were also clearings, but the loggers had made sure to remove every possible inch of wood from the forest. Talking to villagers, Stefan learned that a single local firm was behind most of the logging. The firm was apparently eager to make as much profit as possible, as revealed by the missing stumps and indicated by villagers' resentments against the firm. The firm may not have stolen the wood alike Rudari in Dragomireşti, but forest owners in Dragova felt just as much robbed of their entitlements. Many new owners felt that the firm took advantage of them unfairly.

In both Dragomireşti and Dragova people had lost much of the euphoria prevailing when they became owners of forest just a few years earlier. Joy and elation had given way to disappointment and frustration. The majority of owners in neither commune felt that they got a fair share in the financial benefits derived from forests. Moreover, they felt cheated just as much by the promises of private ownership as by the predatory practices of Rudari and of the logging firm. This chapter examines the reasons for new forest owners' frustrations in Dragomireşti and Dragova. How were Rudari able to exploit forests in Dragomireşti even though villagers held titles to the forest, and although there were forest guards and policemen in place to protect private ownership? What allowed the logging firm to take advantage of new owners in Dragova even though the mayor and Forest Inspectorate had the mandate to enforce regulations on its operations?

Searching for answers to these questions we come to look at the predatory practices of policemen, forest guards and mayors, as they targeted new owners as easy prey. We also examine their efforts to develop relations of patronage with owners and other villagers. Our account thereby uses insights from earlier research on patron-client relationships. ${ }^{1}$ The concept may have dropped out of favor in the more recent literature, but we find certain insights from the literature on patron-client relationships very useful for making sense of forest dynamics in Dragomireşti and Dragova. The insights include the observation that 


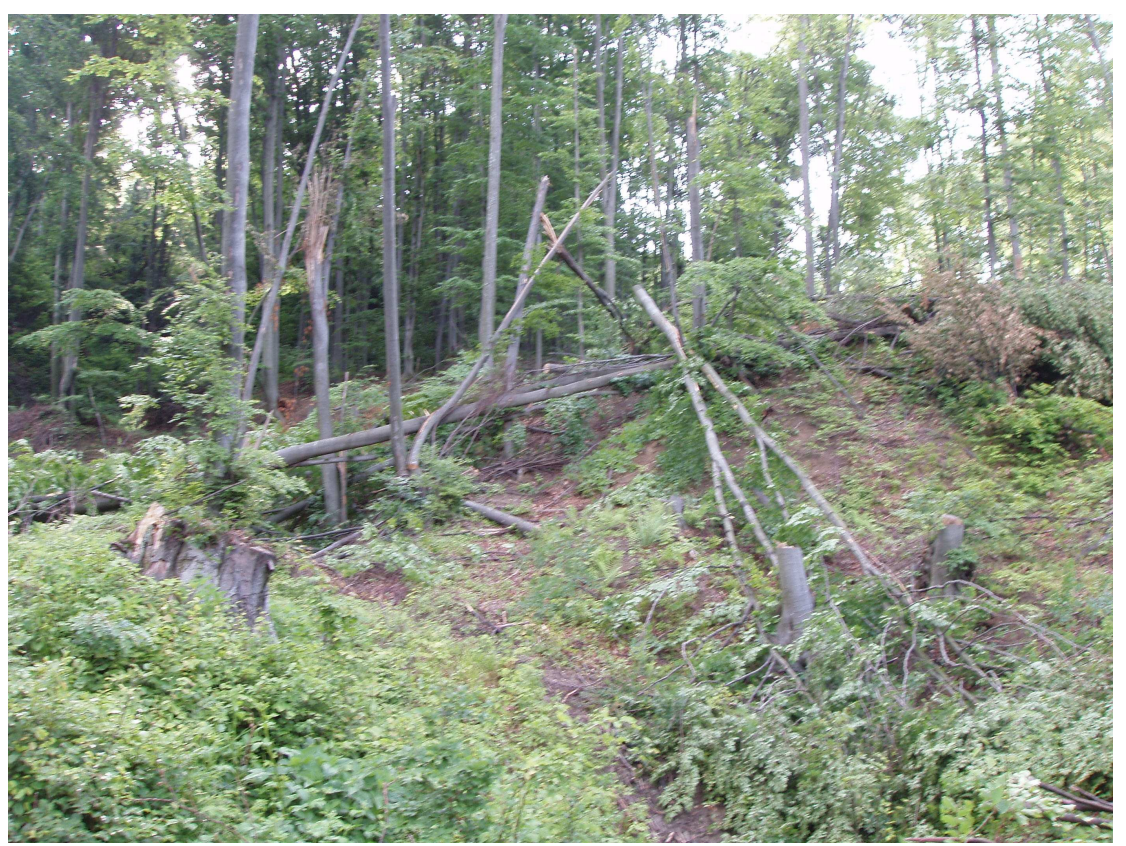

Figure 1: Tree stumps near Dragomireşti

relationships between patrons and clients develop on the basis of unequal power relations. They tend to involve exchanges of economic and political resources, generating benefits for all involved parties even if only nominal in some cases. Moreover, patronage relations are intimately interwoven with the role of the state. Our interest in forest property thus makes us connect with another debate about the nature of the Romanian state, in particular the notion that powerful actors "capture" the local state (Mungiu-Pippidi and Althabe 2002).

\section{Forest restitution in Dragomireşti: the seductiveness of individual private ownership}

"It is my forest. Why does the state regulate how the forest should be used when the forest belongs to $m e$ ?" (Complaint heard frequently in Dragomireşti in 2004) ${ }^{2}$

Villagers in Dragomireşti received forest the first time in 1993. The Romanian Parliament had passed Law 18/1991 in 1991, entitling historical owners or their heirs to a maximum of one ha of forest each, regardless how much they had owned in 1948. People responded enthusiastically in Dragomireşti, as many filed a claim with the Restitution Commission in the commune. As a result, the local Ocolul Silvic Mihăeşti, a division of the National Forest Administration, met with villagers one day in 1993 to sign a protocol about the transfer of 172 ha. The Ocolul Silvic made sure to log over some of the transferred forest before passing it on to the commune. Most of the other forest it gave to the commune was young forest, which did not contain any valuable timber but only firewood at that time. Nevertheless, people from Dragomireşti did receive some forest, as did some other 350,000 Romanians.

Villagers' forest holdings more than tripled in the early 2000s, after Law 1/2000 expanded the maximum forest area that could be restituted to a private owner to ten ha. Villagers received another 428 ha, giving them a total of 600 ha. 152 people could prove ownership of more than one ha in 1948 and received additional forest from the Ocolul Silvic to make it a total of up to ten ha. They joined hundred thousands of other Romanians who lodged similar claims after 2000. In the process, Romania's National Forest Administration passed close to two 
million ha of forest to non-state actors, decreasing the percentage under its management to 65 per cent. ${ }^{3}$

The language of private ownership proved very seductive to villagers in Dragomireşti. Whoever considered themselves entitled to forest went about to get together the required documents and file a claim with the Restitution Commission after Law 18/1991 and again after Law 1/2000. Restitution signified a significant departure from the exclusive state forest management under socialism for villagers. They generally embraced the ideas of private ownership and private enterprise, even though only a fraction actually received titles to forest. Moreover, people cherished the notion of individual ownership. To them, the move away from socialism was only complete if private owners could exercise their new rights individually without any restrictions imposed by the state or collective.

The seductiveness of individual ownership became clear after the Ocolul Silvic handed the forest over to villagers in 1993 not in individual parcels but as a collective holding. The Ocolul Silvic assigned a large tract of forest to the entitled villagers but did not designate the boundaries of individual holdings. The commune council, in turn, decided to regulate the extraction of timber and firewood from the forest and hired a guard to enforce the regulation. The regulations required the new owners to seek permission from the guard if they wanted to exploit their forest. Many new owners resented the regulations and the guard, as it smacked to them like the intrusive state from the socialist past. Private ownership meant to them that they could exploit their own forest at their will: as much as they wanted, at the times they preferred, and in the ways they liked. In short, they did not feel like owners despite their titles. In reaction, some owners lobbied the council heavily to abandon the communal management. They eventually succeeded, causing the council to dismiss the guard, delineate individual parcels and pass those on to individual management (see Figure 2).

Even after the dismissal of the guard, there were a number of local state officials with a legal mandate related to the management, exploitation, transport and trade of forest products. They were in charge of exercising state oversight of forestry as defined in Law 26/1996, which is known as the "Forestry Code" in Romania. In Dragomireşti, the officials included Marian, the local forest guard reporting to the chief of Forest Inspectorate located in Mihăeşti at some $30 \mathrm{~km}$ from Dragomireşti. Marian enjoyed police-like powers, as he let everybody know by carrying a gun around. Another important official was George, a policeman stationed in Dragomireşti. In addition, there was the mayor's office, which administered local records on forest ownership.

New forest owners quickly learned how important the officials were for them even after they had acquired individual ownership titles on forest. Setting out to harvest timber or firewood they first had to send a written request to the mayor's office for verification of forest ownership. As a second step, they had to hire the Ocolul Silvic to prepare an assessment of their forest and to determine the harvest potential. Once the study was complete, the Ocolul Silvic would notify the owner and the forest guard Marian so they could mark the trees to be felled. Only then owners were allowed to harvest their forest. The procedures proved very cumbersome and expensive, a fact that was deeply resented by new owners. There were often prolonged delays in the process, which could mean that a request for firewood submitted to the mayor's office in June may not have generated all required permits until the end of October. Moreover, the procedures were clearly more cumbersome for some than for others who were on good terms with the involved officials or "lubricated" the process through 
additional payments. Marian, in particular, displayed little eagerness to do the required marking if there was no bribe.

When Stefan conducted his fieldwork in Dragomireşti in 2004, virtually every forest owner he met complained about the restrictions on their ownership rights. As Stefan has highlighted at another place (Dorondel 2009), owners perceived a stark discrepancy between the idea of private ownership and their limited ability to harness the significant value of the forest. To them, forest was one of the most valuable local assets. Forest covered some 60 per cent of the commune's territory, including many stands with higher timber volume. Wood was important for heating, helping owners save valuable cash for other expenditures. Moreover, the potential sale of timber was a significant source of cash income, especially when timber prices rose in the late 1990s and 2000s. Timber and wood sales offered a welcome complement to their wages, pensions and social assistance payments. Yet many new owners felt that state regulations threatened to turn the presumable asset into a liability, just as Thomas has observed in other settings (Sikor 2006).

Nonetheless, people's commitment to private ownership went beyond an interest in financial returns. New owners were not ready to give up the idea of private ownership, as they understood it. To them, forest restitution signified a move away from state management. They had become owners and managers of forest, breaking into the monopoly held by the Ocolul Silvic in the past. In people's views this promise of restitution to restore private ownership - seen in opposition to state ownership - was in direct contradiction to the regulations defined in the law and implemented by local officials. People rejected the legitimacy of state regulation, as indicated by the quote cited at the beginning of this section.

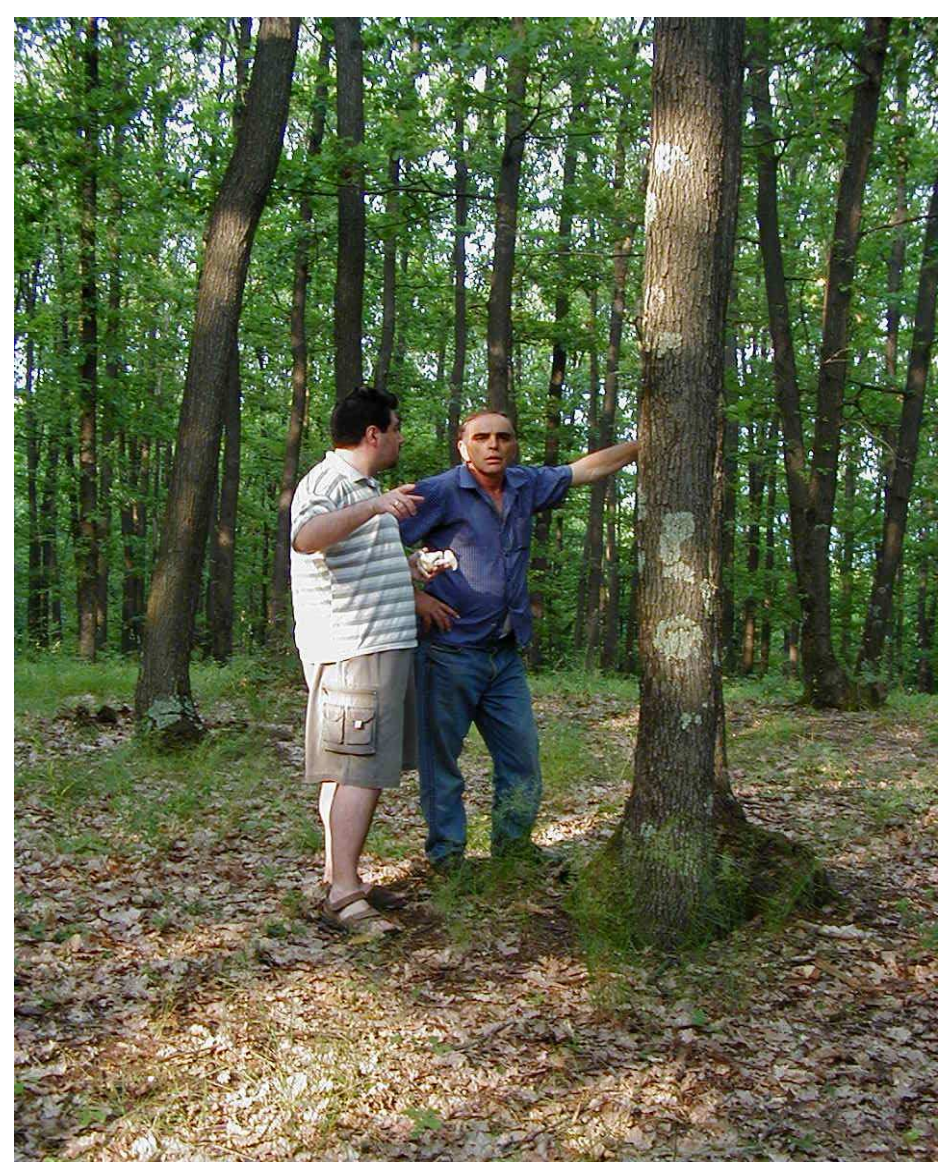

Figure 2: New forest owner showing Stefan his forest 
Moreover, many asserted the primacy of individual ownership, as it meant a departure from collective ownership and collective organization of work during socialism. Even though they had problems to exercise their new ownership rights individually, they did not want to consider cooperative approaches to management. This set Dragomireşti's new owners apart from those in Bulgaria discussed by Cellarius (2004), who embraced cooperative management for its technical and economic superiority. In addition, Cellarius' villagers invoked social memory on pre-socialist forest cooperatives, a historical experience that villagers did not possess in Dragomireşti.

\section{Rudari: out of the woods and back into the woods}

"The forest guards are as bad as dogs." (Rudari saying in the 1930s; Chelcea 1940: 120)

Logging became a more frequent phenomenon in the forests in the commune from 2003 onwards. When Stefan stayed in Dragomireşti in 2004, he often heard the sound of chain saws from the forest. Also, he noted clearings in the forest evidencing recent logging. Yet much of the logging did not involve new owners or happened without their endorsement. When Stefan asked villagers about the logging, he received the unanimous reply that "the Rudari cut our forest”.

"The Rudari" referred to a small settlement at the margins of Dragomireşti. Its inhabitants were Rudari, a relatively small ethnic group in Romania considered to belong to the Vlax Roma. ${ }^{4}$ Neither Romanian nor foreign anthropologists have spent much attention to Rudari. One of the few exceptions is Ion Chelcea, whose books tell us about Rudari history and lives in the 1930s (Chelcea 1940, 1944). Leaving aside some racist interpretations, Chelcea provides us with an ethnographic account of how Rudari sought to eek out a living at the margins of Romanian society. We learn that Rudari lived in or next to the forest, as they did not possess any land and did not have any other way to make ends meet. "We have no country of our own; we settle wherever we find forest", a Rudar told Chelcea (1940: 76). His account matches the stories Stefan heard in the Rudari settlement. "We used to live in the wood", an elderly Rudar told Stefan. They lived not only in the wood, but also half underground in holes dug into the ground covered with roofs. They did not possess any land or forest, many of them working as laborers in a local nobleman's forest. Rudari collected branches from nut trees to weave baskets, used small pieces of wood to make handles for knives and agricultural implements, and gathered wild strawberries, bilberries, apples, raspberries and mushrooms to sell on weekly markets (see Figure 3). Rudari referred to themselves as "worms of the wood", the Rudar confided with Stefan.

The relations between Rudari and the forest guards employed by forest owners were apparently loaded with tension according to Chelcea's account. Rudari cut wood and timber in forests, even though that was deemed illegal by state regulations. They demanded access to forests with the argument that it provided them with resources vital for their living. According to their own regulations, access to forest was open to everybody, and there was no such thing as theft from forest. Rudari also opposed the efforts of forest guards and policemen to enforce their exclusion from the forest. An informant complained to Chelcea that "you can't go in the forest because they (the forest guard, my note) would catch you" (1944: 124). He continued that similarly, "if you go to the market to trade your wooden stuff they (police, my note) ask you for the permit." To avoid detection Rudari resorted to clandestine practices. They would go into the forest after midnight and wrap old blankets or 

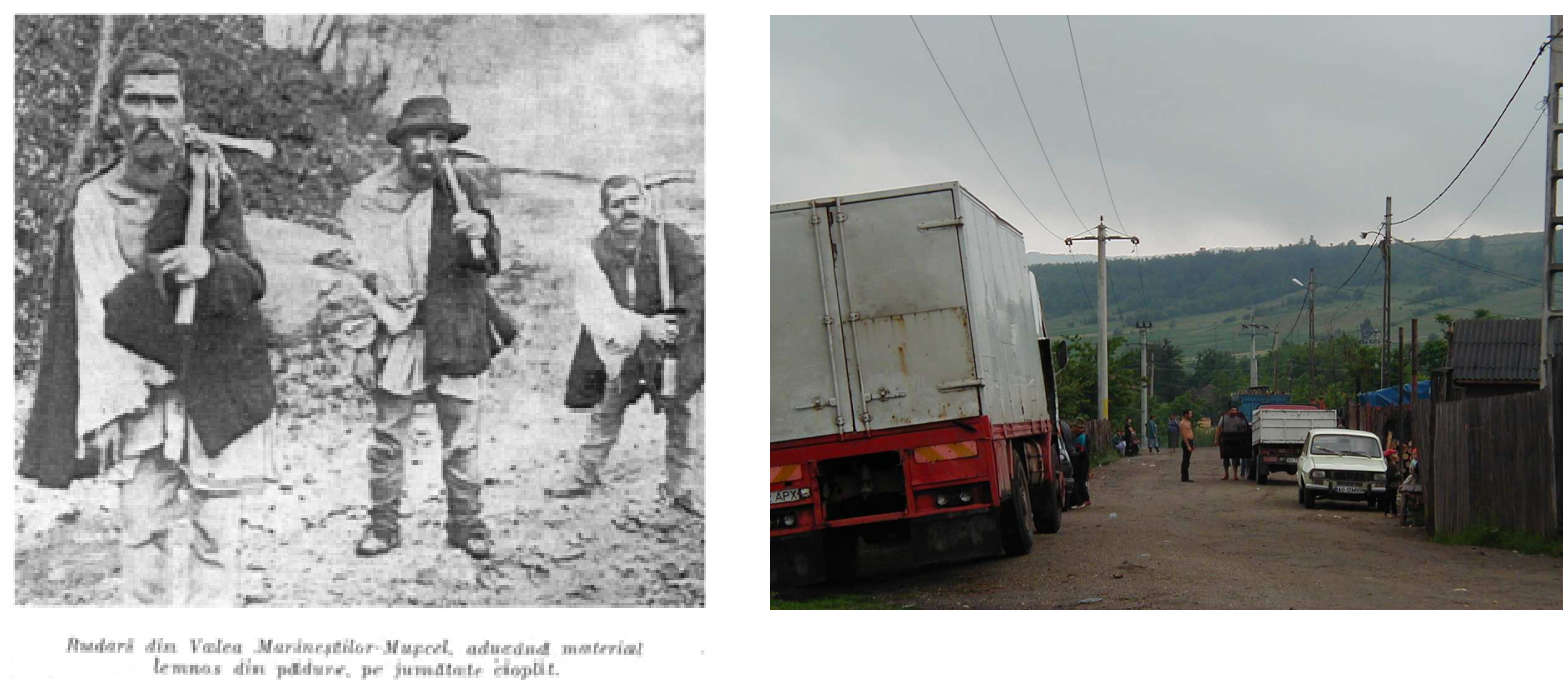

Figure 3: Rudari loggers in 1930s and 2000s

clothes around the trunk of a tree to minimize the noise of their axe. At other times they bribed forest guards, as "for half of kilo of liquor the forest guards would turn a blind eye" (Chelcea 1944: 120). Overall, Rudari were in permanent conflict with forest guards, as highlighted by the quote cited at the beginning of this section.

Rudari told Stefan that their living conditions improved under socialism, resonating with broader accounts of rising Roma living standards during that time. ${ }^{5}$ The Rudari of Dragomireşti continued to make brooms, baskets, pitchforks and other wooden implements. They also helped the forest guards employed by the Ocolul Silvic Mihăeşti to plant trees, weed between newly planted seedlings and conduct thinning. The guards called upon their help and, in return, turned a blind eye on their collection of dry branches and firewood in the state-managed forest. At the same time, Rudari men found work in Dragomireşti's agricultural cooperative or in those of other communes, as cooperatives were chronically short of labor. A few women even found formal employment at the nearby Dacia plant as janitors or in other low-skill positions. In this way, the 1970s and 1980s brought improvements to the livelihoods of the Rudari in Dragomireşti.

Yet as they were coming out of the woods during socialism, they were thrown back into the woods after 1990. Above all, the government's decision to restitute agricultural land and forest to historical owners meant that the Rudari were back to nothing. In 1991, they had to hand back the small parcels of agricultural land that they had just received a year before. The mayor's office had given each household 4,000 $\mathrm{m}^{2}$ in 1990 in line with national policy, but withdrew that when Law 18/1991 mandated the return to historical landholdings. More importantly, they were not entitled to any of the agricultural land and forest restituted to villagers in the 1990s and 2000s. Moreover, the women who had found employment in the Dacia plant were the first to be laid off when the plant trimmed its labor force. Just as Roma in many other places, Rudari were the ones in Dragomireşti who experienced the most radical declines in living conditions and highest rates of unemployment among all kinds of people after $1990 .^{6}$ 
Once again, Rudari had not choice but set out to make a living from the woods. Just as in the past, they went into the forest and cut wood in clandestine ways. Men banded up in small groups, each typically consisting of one person with a horse cart and chainsaw and one or two additional woodcutters. They went into the forest, filled up the horse cart with firewood and returned to their settlement. There the cart owner sold the wood to other Rudari engaged in firewood trade. The traders, in turn, sold the firewood in southern Romania, where people were in desperate need of cheap fuel. Firewood became the key source of income for the Rudari of Dragomireşti, even though its collection and trade was deemed illegal by Romania's laws.

Restitution thus recreated pre-socialist patterns of inequality and injustice. The institution of private ownership, so enthusiastically embraced by new owners and ethnic Romanian villagers more generally, implied flat-out dispossession of Rudari. No Rudari received a single ha of forest during restitution because that was based on historical ownership patterns in 1948. Yet the Rudari's dispossession went beyond matters of asset distribution. As noted by Kaneff (1998), the turn to private ownership reconstituted historical cleavages between ethnic groups. Just as land became ethnic territory in the village studied by Kaneff, private forest ownership was essentially an ethnic Romanian institution in Dragomireşti. In other words, restitution ethnicized private ownership by recreating pre-socialist inequalities. Moreover, the ideology of private ownership devalued social norms and ways of life important to Rudari.

\section{The predatory practices of local state officials}

"The forest guards are worse than dogs." (Rudari saying in the 2000s)

Besides the new owners and Rudari, there was a third group laying their eyes on the forest riches: local state officials. In Dragomireşti, these included the forest guard Marian, the policeman George and the staff of the mayor's office. The new owners had to deal with them when they sought to comply with legal procedures regulating forest exploitation, as discussed above. And it turned out that they also assumed an important role in Rudari logging activities, even though those were deemed illegal by the law.

Rudari were only able to extract firewood from Dragomireşti's forests because Marian and George encouraged that actively. Marian made sure to bump into the horse carts returning from the forest in regular intervals. Every time he encountered a cart he fined the owner a small amount of money (around 14 Euro). This was not enough to stop them from exploiting the forest, but it sufficed as a reminder of his importance. After all, Marian wanted them to know that they risked a fine or even a prison sentence if he reported them to his superiors or the Prosecutor's Office. But he rarely reported anybody. Instead, Marian expected the Rudari to return his favor by delivering logs to his house. His father ran a small saw mill, producing fence posts and wooden elements used in the interior design of houses. The biggest cost to his business was the raw material. Not having to pay for the logs made his business highly profitable. ${ }^{7}$

Marian felt very sure about his influence over Rudari loggers, as Stefan learned one day when hanging out with him. When they heard the noise of a chain saw emanate from a nearby forest, it did not seem to concern Marian at all. "They [Rudari] won't dare to cut trees in the state forest", he said on prodding by Stefan. His confidence rested on the fact that so far no logging had occurred in state forest. ${ }^{8}$ It was astonishing given Marian's own admission that 
he possessed very limited means to enforce his control. He was responsible for around 600 ha but had no off-road vehicles available. It was even more noticeable if one knew that the Ocolul Silvic Mihăeşti held him financially liable for unlicensed logging. He had to pay for every single tree found to be missing from the forest managed by the Ocolul Silvic. Yet Marian was sure that Rudari would not go into state forest, neither this time nor other times. After all, Rudari did not have to go into state forest as there was plenty of private forest now. He had always made sure to explicitly warn Rudari against logging in state forest. He had also made it very clear to Rudari traders that he would only turn a blind eye on their activities if they helped him protect the state forest.

Just Marian, the policeman George made sure to occasionally remind Rudari loggers of his importance. Every other week or so George demanded a bribe from one of the horse carts coming from the forest loaded with firewood. Every once in a while he also levied a fine or initiated legal prosecution procedures against a horse cart driver. In one case, for example, his report led to the arrest of a young Rudar caught red-handed in the forest. It did not matter that the Rudar had a small cart only and was amongst the poorest in the settlement. The poor chap received a prison sentence of six months. His wife, who had just given birth, had to sell the cart in order to survive. In contrast, George never went after the more wealthy and powerful Rudari engaged in the firewood trade. He ignored the trucks parked right in front of their houses, even though between five and ten of them did not possess the mandatory registration (see Figure 3). George even accompanied them sometimes for part of their trip to southern Romania in order to protect them against checks by the highway patrol - for a fee of roughly 40 Euro per truck.

Neither Marian nor George could have engaged in these activities without protection from their superiors. The chief of the regional Forest Inspectorate looked away from the practices of local forest guards. The guards would in return ignore the chief's manipulations of timber auctions and logging in the state forest. They would also campaign for the political party of the chief in local elections. The head of the county police, in turn, not only ignored the practices of local policemen but also benefitted from them financially. The bribes paid in illegal logging operations raised the amount of money he could extract from anybody who wanted to become a local policeman. Lucrative opportunities such as the presence of local wood trade raised the amount job applicants were ready to pay for the position of a local policeman up to 5,600 Euro.

As a result, the new forest owners in Dragomireşti ended up empty-handed where Rudari descended on forest with the sanctioning of local officials. All profits accrued to the woodcutters, cart owners, firewood traders and officials. Comparing gross margins for an average truck, we find that the firewood traders secured almost two thirds of the pie for themselves (190 Euro). ${ }^{9}$ The cart owners (60 Euro) and state officials (48 Euro) also derived significant benefits from the firewood trade. Woodcutters, in turn, reaped only meager benefits from their involvement (12 Euro). Moreover, cutting trees was a dangerous activity, as many of them contracted serious injuries. The local medical worker told us at the end of 2004 that he had treated 14 woodcutters for serious injuries in that year.

Marian and George were not the only local officials profiting from the Rudari's actions in the forest. Staff at the mayor's office had an easy time to convince some of the new owners to sell their forest for cheap. A reference to the Rudari's activities was enough to get some, especially those living outside Dragomireşti, to sell the standing trees in their forest at a price much below their market value. The staff also convinced the owners to sell the trees to them 
in most cases, pretending to help the owners in their predicament. Once the transaction was complete, the staff would immediately sell the trees to logging firms in neighboring villages. In this way, they often achieved unimaginable profits within a matter of a few days or weeks. It was not unusual that they would sell on the trees for ten times the price they had paid to the owner.

Many of the deals involved Iuliana, the agricultural officer of Dragomireşti. Iuliana was in an excellent position to take advantage of new owners because she was the one in charge of restitution procedures. She received the written requests for restitution and issued the documents certifying restitution. In one case, the heir of a historical owner filed a restitution claim to five ha of forest. The heir did not live in Dragomireşti but had long moved to Bucharest. One day, when meeting about restitution procedures, Iuliana pointed the "Rudari problem" out to him. She offered to purchase the trees from him so he would not lose out on the value of his new forest. Furthermore, she indicated that, if they made the deal, she could arrange that his forest would be located not right next to the Rudari settlement but at a safe distance as a way to ensure future harvests. Moreover, she would find a way to arrange the deal in a manner that would help the heir not pay any taxes or fees. Their heir decided immediately to sell the trees on his five ha of forest to Iuliana for less than 3,000 Euro. In the next few days, Iuliana sold the trees on to a logging firm for 28,000 Euro, making a profit of almost 25,000 Euro just on this one deal.

Therefore, new owners were not able to turn their titles into tangible benefits. As much as they valued the symbolic significance of the titles, they quickly became frustrated with the low financial returns. If Rudari descended on their forest, they ended up empty-handed. If they sold the standing trees, they received a low price only. If they still held on to their trees, they were in constant preoccupation that Rudari would come one day or night to cut them. The owners also sensed that they could expect little support from Marian and George. It was too obvious that those showed little concern with the Rudari's activities in private forest, even if they fined a Rudar every once in a while.

The titles so enthusiastically embraced by new owners did not translate into "effective ownership" (Verdery 2003). Just as Verdery finds that agricultural producers in Transylvania are unable to attach tangible benefits to agricultural land titles, we observe a similar inability on the side of new forest owners. Nevertheless, there was a fundamental difference in the processes producing ineffective ownership. Verdery and our own account in Chapter 2 highlight the workings of relatively abstract economic and political forces, symbolized by the downs (and occasionally ups) of agricultural product prices. In Dragomireşti's forests, in contrast, there was nothing abstract about the activities of Rudari and local state officials. The villains for the new owners' predicament were obvious to villagers.

\section{Villagers react: "The law should be enforced!"}

How did ethnic Romanian villagers react to the situation? Above all, they blamed Rudari and called for drastic action against them. Many times Stefan heard in 2004 that " $[\mathrm{t}] \mathrm{he}$ Rudari should be killed since they are not good for anything else but stealing our forest." Although villagers acknowledged that "Romanians cut forest as well" they readily blamed Rudari. Moreover, they portrayed Rudari as people who could not do anything else but steal from Romanians. In addition, it was not only new owners blaming Rudari for the loss of financial value. But virtually all ethnic Romanian villagers, regardless of whether they owned forest or 
not, shared the resentment against Rudari's immoral behavior in the new world of private ownership and private enterprise.

The perhaps best illustration of the resentment against Rudari logging comes from villagers' talk about the tree stumps alluded to in the beginning paragraphs of this chapter. Rudari tended to leave stumps of about one meter height when they logged over forests clandestinely. For people in Dragomireşti that was not only theft but also clear waste, as the loggers had not taken all potential wood. Efficient logging would cut trees as low as possible. Villagers explained the apparent waste with Rudari laziness. Stefan often heard villagers' story that the loggers did not want to bend down when cutting a tree because "the Rudari" were lazy people. In other words, "the Rudari", villagers found, were not up to the new economic order because of an inherent flaw in their character. Villagers did not consider another interpretation, that the loggers may have cut trees at a larger height than usual because that was faster. As the logging was clandestine, and mostly occurred at night, the loggers may have wanted to finish their job as quickly as possible. It was faster to cut trees at one meter height because the diameter tended to be smaller there.

Villagers made Rudari the scapegoat for all things that went wrong in the new world of private ownership. That Rudari loggers exploited forest in an inefficient manner was just the best evidence for them that Rudari were not fit for the economic order. Villagers' talk about Rudari thus mirrored the racist discourse against Roma commonly found in Romania. As Tileaga $(2005,2006)$ notes, this discourse views certain undesirable practices undertaken by some Roma as reflective of the character and way of being of all Roma taken together. It finds its expression in prejudiced and discriminatory statements against Roma found across the whole political and civil spectrum in Romania. For example, in a Gallup poll in 2003, four out of five respondents believed that the vast majority of Roma break the law. More than one third believed that Roma should be forced to live separately from the rest of the society because they could not integrate. C.V. Tudor, a right-wing politician who achieved a 30 per cent share in the 2000 presidential ballot, called for isolating "Roma criminals in special colonies". This racist discourse ignores the political economic context in which Roma act, as it became apparent in Dragomireşti. Ethnic Romanian villagers readily ignored the fact that the restitution of agricultural land and forest had left Rudari empty-handed, and that Rudari had been the first to loose jobs in the down-turn of the 1990s.

Villagers reacted by calling for law enforcement. They appealed to the state to protect private ownership and to prosecute infringements on private ownership - with mixed success. On the one hand, some owners with large forests reported tree theft to the County Police on several occasions. Their reports caused special police forces to come to Dragomireşti repeatedly, some times in the middle of the night. Yet the police was unable make any arrests. The owners' suspicion was that an insider had warned the Rudari loggers to stay home when a police raid was imminent. That insider, they suggested, could only be George or Marian. On the other hand, Stefan heard in 2006 that justice finally caught up with George. Special police forces arrested him on corruption charges, and he was forced to retire.

Villagers called for law enforcement even though they knew of local officials' complicit behavior and active support for illegal extraction. They were aware of the fact that Marian's father ran a wood processing company out of the forest guard's house, despite a regulation banning forest guards from engaging in the wood business. They were sure that the timber stacked around their house originated from Rudari logging. Moreover, villagers noticed that the candidates in the 2004 local elections circumvented any clear statement against Rudari 
logging in a televised public debate. Three days before the final ballot, neither of the leading two contenders wanted to acknowledge that there was deforestation, and that Rudari may extract wood illegally. The race being very close neither candidate wanted to risk Rudari votes, as Stefan has discussed at another place (Dorondel 2009).

Nevertheless, a few owners initiated actions against local state officials to enforce their compliance with the rules of private ownership. How hard it was for new owners to get local officials to comply with the law became clear in a legal case brought by Dr. Popescu against Dragomireşti's bookkeeper. Dr. Popescu lived in Bucharest, where he worked at the Romanian Academy of Sciences. In 2003, he received ten ha of forest in the village, as his father used to own a large tract of forest in the past. Hearing about Rudari logging, he decided to harvest the forest before Rudari could descend on it. He went to the mayor's office to inquire about the applicable procedures. At the office, he came to talk with the bookkeeper, who offered to help him with the procedures and, for a small payment, to connect him with a logging firm. Dr. Popescu paid 3,000 Euro to get the required permit but hired another firm to do the cutting. When the bookkeeper heard that another firm had started to cut trees in Dr. Popescu's forest, he suggested to Rudari to exploit the forest. He was in a powerful position towards them, as he was the one paying out social assistance payments to them. He had also become a godfather for several Rudari children, indicating the close relationship. Some Rudari, in turn, did not hesitate long but went to Dr. Popescu's forest, threatening the workers of the logging firm and forcing them to abandon their job after just one fifth of it. They finished the job within a short time.

Dr. Popescu did not want to accept the fait accompli unlike many other owners. He went to Dragomireşti, as soon as he heard from the logging firm that they had withdrawn from the job. Yet when he inspected his forest, he discovered that there was not a single tree left. In reaction, he filed a complaint with the police in Dragomireşti. When he saw that George had little inclination to act on his complaint, Dr. Popescu reported the incident to the national police headquarters and the National Department of Anti-corruption in Bucharest. By the time Stefan finished his fieldwork in 2004, the national-level police units had nearly finished their investigation. They expected to try the accountant in front of a court. Other staff in the mayor's office commented on the case that it was an unfortunate combination of excessive greed on the side of the bookkeeper and an unusually assertive owner. If the bookkeeper had been a little bit more careful, or if it had been an average owner, the two would have cut a deal.

Three years later, Stefan heard that it had not come to a court case. Even more surprisingly, the bookkeeper was now the new mayor. At the end, Dr. Popescu and the bookkeeper cut a deal. Dr. Popescu dropped his case against the bookkeeper. The bookkeeper, in turn, made sure that Dr. Popescu's request for the restitution of an additional 900 ha was successful. That request became possible after Law 247/2005 removed the previous limits on the maximum area of forest that could be restituted to individual owners. It saved the bookkeepers political career and personal fortune. Dr. Popescu explained to Stefan that he was glad to avoid the hassles of court proceedings and, above all, wanted to make sure to get all of his father's forest restituted. He allegedly sold the harvest on the restituted forest for one million Euro.

These events indicated how villagers called upon the state to protect private ownership by enforcing the law. When Rudari loggers did not comply with the rules of the new economic order, they called for an enforcement of state regulations protecting private owners. When 
they saw local officials predate on their forests, they appealed to higher-level organs of the state to enforce the law. Their responses portrayed significant trust in the rules and procedures instituted by the Romanian state after 1990. Villagers, including owners and nonowners alike, called upon law enforcement, even though new owners loathed the restrictions imposed on their own forest management. With this, we want to leave Dragomirești behind and turn our attention to Dragova, our other case study in Romania. New owners in Dragova, we will show, also faced problems to exercise their newly acquired forest titles, yet for different reasons.

\section{The mayor and new owners in Dragova: predator and prey}

Just as in Dragomireşti, a significant number of people in Dragova received titles to forest in the process of restitution. Villagers filed their claims for the restitution of one ha with the local land commission after Law 18/1991. Many went back to the commission in the early 2000s, after Law 1/2000 expanded the maximum allowable area to ten ha. 92 people received forest titles for a total of 879 ha this way. In contrast to Dragomireşti, they acquired individual titles from the beginning. But just as in the other commune, much of the "forest" conferred to villagers in the first round was young forest that the Ocolul Silvic Rucăr had logged over and replanted just a few years before. ${ }^{10}$ This situation changed dramatically, however, in the second round when the Ocolul Silvic transferred not only a much larger area but also significantly richer forest to villagers.

The incipient privatization of the forest sector called a middle-aged couple, Maria and Ion, on the plan. Ion had managed the cooperative guesthouse in Dragova under socialism. After its demise, Ion and Maria opened a small store selling locally produced smoked cheese to visitors. When they saw later that the state was transferring some forest to private owners and created opportunities for private involvement in wood processing and trade, they sensed a unique business opportunity. In 1993, Maria and Ion started up a private logging firm, initially exporting small numbers of wooden logs only. Yet over time, their business flourished and expanded, which eventually allowed them to purchase three trucks in addition to several leased ones. Until 2004, when Stefan came to Dragova, their firm remained the only one in the commune. Thus, they were more successful than the many other private logging firms in Romania that emerged in the 1990s but ceased operations a few years later.

One of the reasons why their logging firm was so profitable was that Ion decided to run for mayor in 1996 and won the election. He ran as a candidate of the Liberal Party, which by no coincidence was one of Romania's political parties in favor of expanding the maximum area for restitution to ten ha. Ion successfully sought an extension of his term in 2000. His reelection put him into a very advantageous position when it came about implementing Law 1/2000: he was the head of the commune-level restitution commission. It did not matter to him that he had to formally resign from his firm in 1996, when he was elected mayor the first time. Maria took over sole responsibility for the firm in front of the law. For villagers it was clear, however, that they continued to run the firm together.

Maria and Ion did not waste the opportunity to influence the restitution of forest to their personal advantage. Even though Ion could not do much about the area that successful claimants received, he had a lot of leverage on what quality of forest villagers received, and in what location. Both forest quality and location made a big difference for an owner's possibilities to derive financial return from forest. Ion used his leverage to transfer a lot of the 
high-value forest to old people in the commune - not for reasons of charity but because it was easier to convince them to sell the harvest to Maria's firm.

When Stefan was in Dragova in 2004, villagers repeatedly told him the story of Angela. Angela was already some 65 years old, lived all by herself and did not get around much. In 2003 she was pleased when the restitution commission an additional four ha to her. Living of a meager pension of around 100 Euro a month, she became even more excited when Maria offered to buy the harvest on the five ha for around 4,000 Euro. She happily took the money and let Maria's logging firm log over the forest located right along the main road. The location made it easy and cheap for the Maria's woodcutters to get the trees out. Although Stefan never found out for how much Maria sold the timber harvest, she could easily have gotten 200,000 Euro at current market prices, which is 50 times the price she paid to Angela! ${ }^{11}$

Angela's story thus provides another illustration for how new owners fell prey to local state officials in the wake of restitution. Ion abused his office for his personal gains just like George, Marian and the staff at the mayor's office in Dragomireşti. Nonetheless, the predatory dynamics in Dragova were different from those in Dragomireşti. In Dragomireşti, appointed local officials took advantage of their positions to derive personal benefits. In Dragova, a private entrepreneur decided to run for public office and then used his position as mayor to promote the interests of his private business. In this way, Maria and Ion sought to merge the public conduct of local affairs with their private business dealings. They achieved

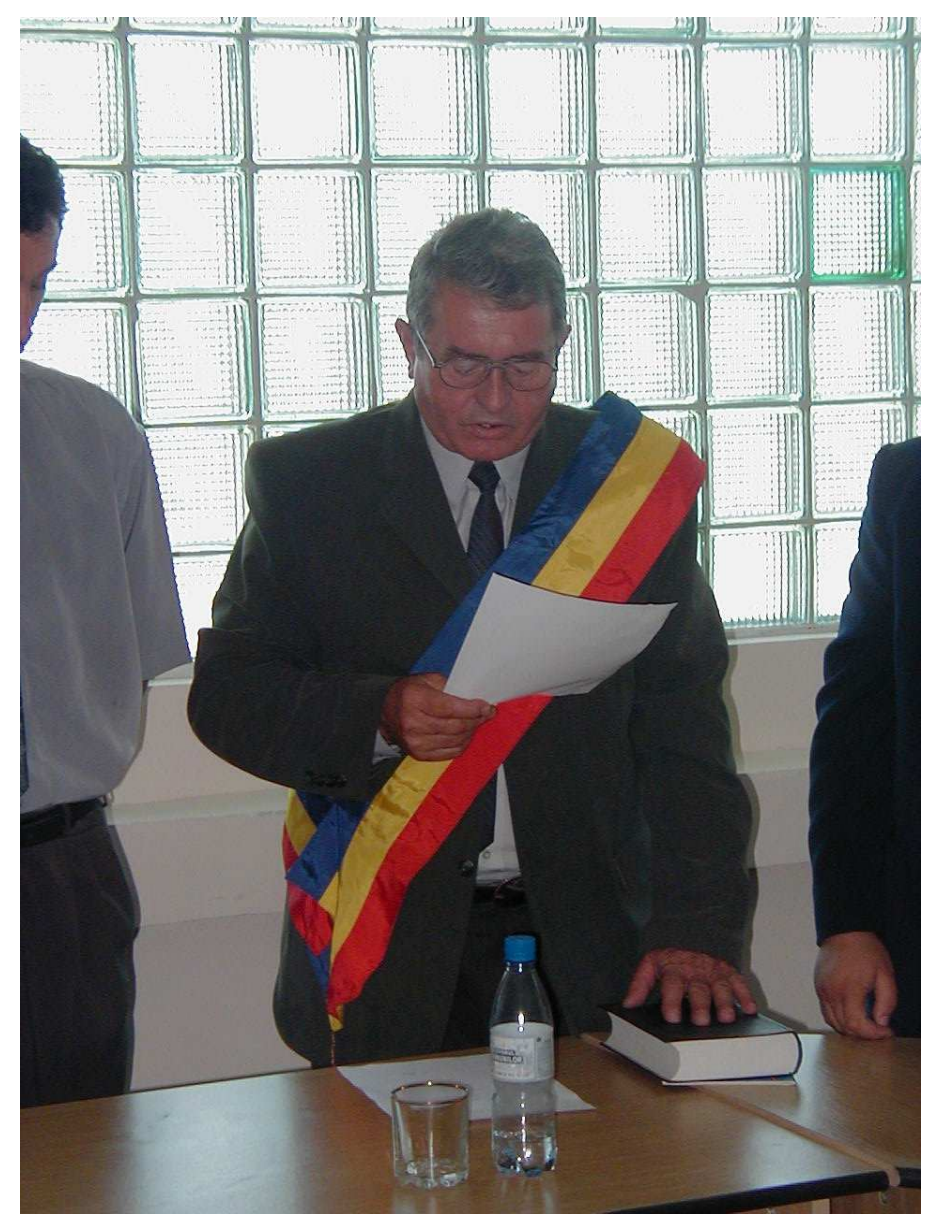

Figure 4: A Romanian mayor taking the oath (not the one in Dragova) 
their goal by influencing restitution. They also found ways to use the adjacent National Park Piatra Craiului for their personal gains, as we have discussed at another place (Stahl et al. 2009). Ion basically suggested to the owners of forest located in the park's protection zone to sell their trees to Maria's firm before the park could ban any further exploitation.

\section{The shrinking collective forest}

Ion also found a way to twist the restitution of a collective forest to some families in Dragova to his personal benefit. After Law 1/2000 expanded restitution to include collective forest holdings, villagers filed a claim with the restitution commission on behalf of a few families. They reported that the families had jointly owned forest on Dragova Mountain, a small mountain within the commune's borders. Now they wanted the commission to restitute what villagers commonly referred to as the "small collective forest" to them.

The villagers even produced historical documents that specified the total surface of the small collective forest as 52 fârtare. The problem was that nobody knew exactly how big a fârtar was. In addition, the historical records accepted by the restitution commission indicated that the small collective forest was on Dragova Mountain, but they did not show any boundaries. Some elderly villagers asserted that a fârtar was equivalent to six ha. An elderly man was even in the possession of a technical study from 1936, in which an engineer reported Dragova Mountain to measure 300 ha. The report stated clearly that 52 fârtare were equivalent to 300 ha. The old men had hidden the report during socialism in a secret place, as it was illegal to keep old records. He had hoped that one day it would become useful as evidence for their historical forest holdings. Yet the report was not recognized by the restitution commission as valid proof.

The restitution commission decided in 2004 that a fârtar was equivalent to three ha only and conferred rights to 156 ha of forest to the families. The commission maintained that there was no legally valid evidence that a fârtar was six ha. Its decision received the backing of the regional restitution commission in Pitesti, to which the families had appealed. The regional commission stated that they did not know the size of a fârtar and referred the case back to the local commission. As a result, the small collective forest got even smaller, shrinking from 300 to 156 ha. The forest thus met the same fate as some of agricultural land discussed by Verdery (1996). Land, Verdery finds, was surprisingly elastic during restitution, expanding and shrinking over time and between the accounts of different actors.

As noted by Verdery, the elasticity does not work in everybody's favor. It affords maneuvering space to the powerful, such as Maria and Ion in Dragova. The couple was in a powerful position to exploit the ambiguity around the small collective forest: Ion was the head of the restitution commission. In addition, the restitution of the small collective forest had direct bearing on their interests. From an economic viewpoint, they had strong reasons to make the collective forest shrink, as it was much easier to convince the owners of small individual forest holdings to sell the harvest to them. The owners of the collective forest would have been in a much stronger bargaining position and may have undergone the trouble to approach other firms. From a political perspective, Ion also had important reasons for reducing the size of the collective forest. The shrinking collective forest created space for political maneuvering. As nobody else could make a legally valid claim on this forest, he had 150 ha available to restitute according to his own preferences. He now had plenty of possibilities to use the remaining forest on Dragova Mountain for creating personal allegiances and favoring his allies - and he used them, as we will discuss a little later. 


\section{The mayor's manipulation of timber auctions}

Law 1/2000 also led to the restitution of a communal forest in Dragova. Its origins date back to the time after World War II, when the Romanian state rewarded some veterans in the commune with small forest parcels. A few years later, in 1948, when the socialist regime was about to nationalize all forest in Romania, the veterans decided to jointly transfer their ownership rights to the commune. Their action did not prevent nationalization and the loss of the forest, yet it implied that the commune now possessed a legally valid claim on the forest. As a result, the commune received 70 ha of forest in 2003, just as local councils received a total of 750,000 ha in other parts of Romania. The understanding within the local council was that the forest should be used to supply fuel wood for Dragova, in particular heating for the schools, church and houses of poor and elderly villagers. The commune council approved several sales of firewood from the forest at a price below market rates to needy villagers.

Ion was not satisfied with the subsistence use and lobbied for the commercial exploitation of the communal forest. He got his way when the commune council approved his proposal to repair local roads and raise the required finance by logging over the communal forest. What looked like sensible public investment and good use of the communal forest, however, worked heavily in favor of Ion and Maria. Their heavy logging trucks were one of the main causes for the bad state of the roads in Dragova (see Figure 5). The bad state had become the focus of villagers' ire. In reaction disgruntled councilors had introduced several motions to the commune councils requesting that the commune collected the fee levied on all cars

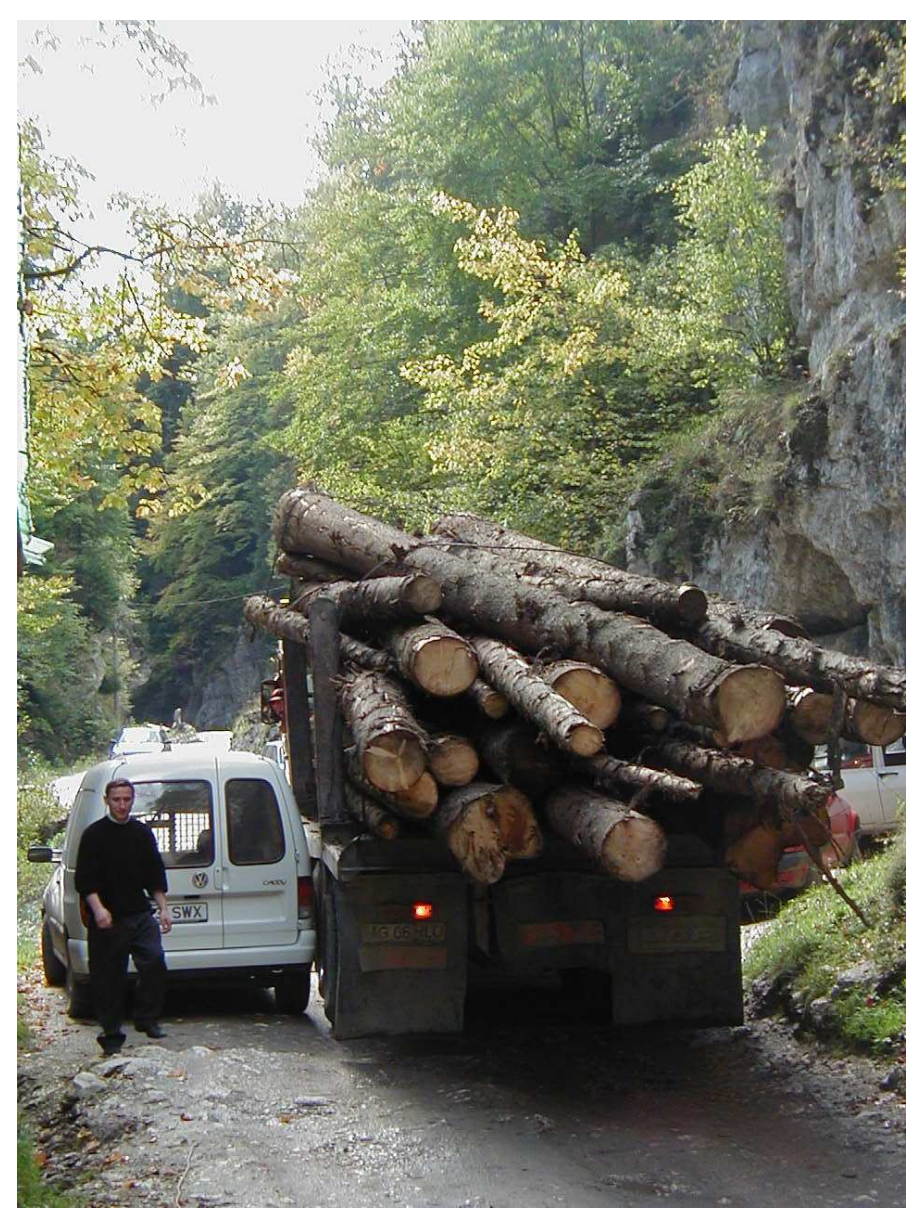

Figure 5: A logging trucks bullies its way through Dragova 
visiting Dragova also from Maria's trucks. Even though the council upheld the exemption, the road repair decided by the council came very welcome to Maria and Ion. Moreover, it was Maria's firm that got the contracts to log over the communal forest.

Maria's firm won all the auctions for the communal forest. Such auctions were another centerpiece in Romanian forestry legislation. Already in 1991, Ministerial Order 572 mandated that all timber sales from state forests to private enterprises had to involve auctions. Four years later, Government Decision 342 created a consistent and comprehensive legal basis for the auction system. Another legal act in 1998 expanded the auction system to include forest under the jurisdiction of local councils. The legislation mandated that auctions needed to be announced at least 30 days in advance, and in at least two newspapers. They had to include at least two registered bidders. By way of the regulations, the central government sought to ensure that private enterprises participated in the auctions on an equal footing. The expectation was also that auctions would prevent collusion among potential buyers and between firms and state officials, thereby minimizing predation on the revenues from state and communal forests.

Despite the regulations, Ion arranged for Maria's firm to win all auctions for the communal forest. In charge of organizing auctions for the commune, Ion tilted the playing field in Maria's favor by announcing an auction only a few days before the event, and posting a small advert in a local newspaper of limited distribution only. As a result, competing firms had a few days only to register their interest and get the necessary paperwork together. In contrast, Ion had informed Maria long time before, giving her firm ample time to get a bid together. Moreover, Ion and Maria took care to organize another bid for the auction so it passed the regulatory requirement. They asked a friend, who also owned a logging firm, to submit a pro forma bid so the auction could be held. It worked for them, as it did in many other places in Romania. ${ }^{12}$

Ion thus made his position as mayor beneficial to their logging business in many ways. The benefits did not end with his influence over the restitution process and auctions. His position also allowed his wife to employ poor fellow villagers cheaply. Maria did not give them any regular contracts and did not register them for social benefits. Furthermore, his position protected him from the law enforcement efforts of the Forest Inspectorate. That was important because Maria's firm, just as many others, often harvested forest without getting the required permits, or cut a larger volume than allocated in the permit. Whenever the Inspectorate was about to send in officer, Ion was among the first to find out. This gave Maria enough time to send the workers home and hide the trucks. So it happened one day that Stefan waited for hours in the commune center for a ride on one of the logging trucks, without any one passing by. On any other day, he would have caught a ride within an hour. Only the next day Stefan found out that Ion and Maria had expected an inspection team and had kept the trucks in the garage.

\section{The challenge of staying in office: the mayor's campaign in 2004}

"The mayor has high-level connections. If you fight with him you fight with the state. You can't win when you fight with the state." (A villager involved in a land dispute with the mayor)

His predatory actions presented Ion with a massive challenge when his second term was coming to a close: how could he get the people of Dragova to give him another term in office? 
The situation was different from 2000, when he successfully ran for reelection the first time. Since then his predation on the new owners' forest had been particularly egregious: Ion manipulated the restitution of individual forest, reduced the collective forest by half and influenced the auctions for timber from the communal forest for his personal gains.

Moreover, he and his wife were the obvious culprits for why many new owners derived little financial returns from their forests. His electoral competitor announced that he would initiate investigations on the implementation of forest restitution and the contracts with Maria's firm. In addition, there was a lot at stake for them, as Maria had just taken out a bank loan over 130,000 Euro to purchase additional trucks and bid for forest concessions.

Ion got the third term in office that he wanted so desperately. He won the elections with the slightest margin possible, as his Social Democratic Party won only three of the nine seats on the council. Ion still managed to win, partially through the political maneuvers that are so common to local elections in Romania. Ion portrayed himself to the electorate as a hard working guy (gospodar). He cut a deal with the local head of National Liberal Party, which was not only the main opposition party nation-wide but had also gotten the head elected as the vice-mayor in 2000. He convinced the head to stay out of the race and instead support Ion's campaign. He also made another deal with a former vice-mayor, granting him the permission to turn the public bus stop into a private parking lot for his restaurant in return for political support. So when the elections came around, he was able to count on not only the additional support of two influential men but also their extended families in Dragova. Furthermore, Maria and Ion spent some of their personal wealth on small presents for old people. Ion personally delivered packages containing flour, sugar and other basic food items to them, engaging in the kind of "vote buying" that newspaper reported as a widespread phenomenon in the elections of 2004.

Ion did not miss the opportunity to take advantage of his influence over forest restitution for his political aims. Villagers generally considered him to give preferential treatment to people from Podu, the largest settlement in Dragova, where Ion and Maria lived. In this way, many told Stefan, he demonstrated to them that they had something to lose if he was voted out of office. How he made use of his position as the head of the restitution commission became especially apparent in a case, where even a position in the mayor's office did not protect a woman from falling prey to Ion's maneuvers. Mariana worked in the office under Ion. She tried hard to support her father's claim for the restitution of four ha near his house. Her father had received one ha close to his house in the early 1990s already. The restitution commission had also validated his right to receive another four ha of forest after Law 1/2000. Her father wanted to get all his forest right in a single location and close to his house because that would have made its management a lot easier. He also argued with the commission that it was exactly this forest that his father had owned prior to nationalization in 1948. Yet despite support from Mariana, the commission eventually decided to allocate the additional four ha to him at a different, remote location. As Mariana told Stefan, the forest was too valuable for Ion to miss the opportunity. It contained mature trees and was very accessible. So Ion took advantage of her absence from office, when she spent two weeks on the Black Sea on vacation. During her absence Ion arranged for the restitution of the forest to a friend of his who had supported Ion during the electoral campaign in 2000. The friend had no proof of historical ownership for any forest at all. Yet that did not matter.

Finally, Ion made sure to build good relations with external actors - and to demonstrate to villagers the backing he received from outside. He switched to the Social Democratic Party, one of the major parties in Romania in 2004. He also promised the villagers to get funding 
from the European's Unions PHARE program to construct new roads, something that the hotel owners, guesthouse operators and people living in more remote parts of Dragova liked to hear. He even arranged for a visit by the president of Romania's national parliament, the second most important office in Romania, to Dragova. Furthermore, Ion proved outstanding diplomatic instincts in his dealings with Piatra Craiului National Park, as we have discussed at another place (Stahl et al. 2009). He presented himself to villagers as a protector of their interests against the park. At the same time, he managed to appease the park management by maintaining a surface of compliance with their demands.

These observations show how Ion was able to build and sustain relations of political patronage. He not only built a powerful network of allies in Dragova, but also used his external contacts for his political purposes. Many villagers harbored a feeling of impotence, as illustrated by the quote at the beginning of this section. They noted his "high-level connections" and concluded that "[i]f you fight with him you fight with the state." The state, in turn, was still a powerful institution in people's views. It made little sense to contest the state: "You can't win when you fight with the state." They were convinced that that Ion enjoyed strong support from the central government, as observed by a middle-aged man: "All people from this village know that he is well known in the central government as well. We know his power". To many of them, Ion was the state.

\section{Property, predators, patrons and the state in Dragomirești and Dragova}

We find that new owners embraced their forest titles in Dragomireşti and Dragova, as the titles meant to them the right to exploit an important economic asset. Moreover, owners and non-owners alike welcomed the titles as a signifier for the departure from the restrictions on their productive activities and personal lives under socialism. The language of private ownership was highly seductive to them, as it promised unlimited freedom in the pursuit of prosperity. Yet new owners quickly fell prey to the actions of powerful local predators. Despite holding ownership rights, many villagers did not derive significant economic benefit from forests. Much of the value contained in their forests accrued to local state officials, wood traders and logging firms. As a result, much of the enthusiasm about private ownership in the 1990s gave way to disappointment.

The cracks in the image of private ownership found reflection in the forest landscapes of the two communes. Logging drastically rose in 2003, when the forest area and quality under private ownership increased as a consequence of expanded restitution. By the end of 2004, forests had already vanished on around 130 ha (roughly five per cent of the total forest area) in Dragomireşti and another 130 ha (four per cent) in Dragova. Moreover, private ownership affected people's visions of a desirable forest landscape. New owners and predators combined in an unhealthy coalition that saw forests as a source of short-term financial returns. New owners wanted their forests to enhance their incomes and to allow the exercise of personal freedom in economic affairs. For their predators, forests became a financial asset to be exploited for maximum profit.

Underlying the unraveling of private ownership and short-term exploitation were powerful relations of patronage. The significance of local patronage set the forest dynamics apart from those observed in agriculture (the subject of Chapter 2 in our book). In agriculture as in forestry, many new owners were unable to translate their rights into tangible benefits. Nevertheless, underlying their inability in agriculture was the corrosive influence of more abstract processes of devaluation and revaluation. In forestry, the exploitation of new owners 
was much more concrete. New owners struggled against the predatory practices of local actors, who sought to appropriate the riches of the forest by various means. Local state officials, traders and logging firms accrued profits by way of influencing the restitution process, manipulating permits and auctions and controlling wood markets, even though they did not own any forest. Struggles over forests, therefore, were about the significance of private ownership as a means to secure tangible benefits from valuable resources.

The patronage relations took different forms in the two communes. In Dragomireşti, local state officials took advantage of a highly unequal distribution of productive resources recreated by restitution. The injustice prepared the grounds for them to incite and exploit practices on the side of the disempowered that were deemed illegal by Romania's legislation. The situation was a fundamentally different one in Dragova, as there was no marginalized group to abuse and not much space for illegal operations. In Dragova, the head of a local logging firm felt compelled to seek election as mayor. Once in office, he resorted to tactics that stretched the limits of his formal powers as sanctioned by the law. At the same time, the mayor never employed the illegal and violent practices used by state officials in Dragomireşti.

The involvement of local state officials reveals how the negotiations about property were simultaneously contestations over the state. In contrast to the Albanian cases (the subject of Chapter 4 in our book), property negotiations never challenged the authority of the state per se. Instead, people's struggles over property were about different forms of exercising state authority. From the perspective of people in Dragomireşti, the extension of forest titles served to reconstitute the authority of the Romanian state over forests on a new basis. This basis rested on the positive notions villagers attached to private ownership and the need for the state to enforce ownership rights. When they saw Rudari and local officials encroach on their rights, they responded by calling for protection by the state and law enforcement. In this way, they separated the practices of Rudari and officials from the law, demanding compliance with the law. The paradoxical result was that both the institution of private ownership ad its unraveling served to enhance the legitimacy of the Romanian state in their eyes. Villagers wanted a state that exercises its authority over forests by way of abstract rules and procedures. Such a state was particularly important when local officials tried their best to ignore and undermine these rules, as Verdery (1996: 213-5) notes in her discussion of land reform in Romania.

In comparison, new owners underwent little effort to reign in on the mayor's practices in Dragova. Of course, many voted for his competitors in elections. Yet once he was in office they did not think they could do much against his manipulations and maneuvers. People's feeling of impotence indicated how the mayor was able to move towards a personalized style in the way he managed communal affairs. He managed to "capture" not only the local state (Mungiu-Pippidi and Althabe 2002) but also the state as an idea in local people's minds. Many people in Dragova virtually equated the mayor with the state, just as mayor Lupu in Verdery's account (2002). As a result, the exercise of state authority over forests took on a different quality in the two communes: Dragova's mayor was much more successful in making his case for a personalized exercise than the officials in Dragomireşti.

The intimate connection between postsocialist struggles about property and contestations over the exercise of state authority is a theme that remains with us in the following chapter. Shifting our attention to Vietnam, we may make a radical change in geographical settings. Yet, as will soon become apparent, property dynamics regarding forests were as much about 
the conflict between rule-based and personalized forms of exercise state authority in Vietnam as in Romania.

\footnotetext{
${ }^{1}$ For useful overviews see Eisenstadt and Roniger (1980) and Littlewood (1980). As emphasized by the former, it is useful to consider patron-client relationships not as setting up simple dyadic relationships but as part of complex hosts of social relationships. See also Berry (1985) and Hart (1989) on political patronage.

${ }^{2}$ All translations are our own unless stated otherwise.

${ }^{3}$ Ioras and Abrudan (2006) estimate that the more recent Law 247/2005, which mandates the restitution of all forest to former private owners, will further lower the percentage under state management to 35 per cent.

${ }^{4}$ The Vlax Roma are most likely descendents of slaves in the Romanian-speaking lands north of the Danube river and are different from the Balkan and Western European Roma (Chaix et al. 2004). The number of Rudari in Romania is unknown because the Romanian state does not recognize them as a separate ethnic group. They are instead lumped together with other Roma groups in the official population census, which has attracted criticism by Rudari and scholars in Romania. The census yields a share of two percent for the Roma population in Romania, but other counts put the share as high as 15 per cent. classificatory difficulties. On a more general note, we recognize that the ethnic categories are problematic and do not want our use of the terms 'Rudari' and "Roma' to imply any judgment about their appropriateness.

${ }^{5}$ Brearley (2001).

${ }^{6}$ Brearley (2001).

${ }^{7}$ Note the parallel with the practice under socialism that forest guards looked away from Rudari firewood collection in return for their help in forest management.

${ }^{8}$ A participatory mapping exercise with villagers produced convincing evidence that no logging had taken place in state forest (Dorondel 2009).

${ }^{9}$ Gross margins are revenues minus variable costs excluding labor. To get from gross margins to profits one needs to subtract the costs of capital depreciation and labor.

${ }^{10}$ This was very apparent from a map on forest conditions and forest tenure that Stefan drew with the villagers. All the forest that the Ocolul Silvic had exploited in the 1980s went to villagers in the first round of restitution.

${ }^{11}$ This is how we arrive at our estimate: (a) Maria purchased five ha; (b) Grodzińskca et al. (2004) estimate the average timber volume in Carpathian forests of Romania as between 300 and $400 \mathrm{~m}^{3}$; and (c), the price of timber was 200-380 Euro $/ \mathrm{m}^{3}$ for beech and $95-140 \mathrm{Euro} / \mathrm{m}^{3}$ of spruce fir. This gives a range of potential revenues from 142,500 Euro to 760,000 Euro. One would need to subtract costs to arrive at profits.

${ }^{12}$ Saphores et al. (2006) provide statistical evidence for collusion in two forest directorates of Romania.
} 